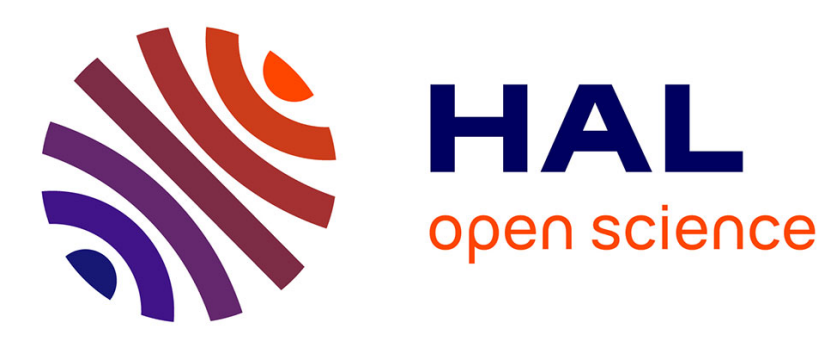

\title{
Effect of Geogenic Lead on Fungal and Collembolan Communities in Garden Topsoil
}

Sophie Joimel, Hervé Capiaux, Christophe Schwartz, Mickael Hedde, Thierry Lebeau, Cécile Le Guern, Johanne Nahmani, Céline Pernin, Sandrine Salmon, Lucia Santorufo, et al.

\section{To cite this version:}

Sophie Joimel, Hervé Capiaux, Christophe Schwartz, Mickael Hedde, Thierry Lebeau, et al.. Effect of Geogenic Lead on Fungal and Collembolan Communities in Garden Topsoil. Pedosphere, 2018, 28 (2), pp.215-226. 10.1016/S1002-0160(18)60022-0 . hal-01783981

\section{HAL Id: hal-01783981 https://hal.science/hal-01783981}

Submitted on 26 May 2020

HAL is a multi-disciplinary open access archive for the deposit and dissemination of scientific research documents, whether they are published or not. The documents may come from teaching and research institutions in France or abroad, or from public or private research centers.
L'archive ouverte pluridisciplinaire HAL, est destinée au dépôt et à la diffusion de documents scientifiques de niveau recherche, publiés ou non, émanant des établissements d'enseignement et de recherche français ou étrangers, des laboratoires publics ou privés. 


\title{
Effect of Geogenic Lead on Fungal and Collembolan Communities in Garden Topsoil
}

\author{
Sophie JOIMEL ${ }^{1,2,3, *}$, Hervé CAPIAUX ${ }^{4,5}$, Christophe SCHWARTZ $^{1,2}$, Mickaël HEDDE ${ }^{3}$, Thierry LEBEAU ${ }^{5,6}$, \\ Cécile LE GUERN ${ }^{5,7}$, Johanne NAHMANI ${ }^{8}$, Céline PERNIN ${ }^{9}$, Sandrine SALMON ${ }^{10}$, Lucia SANTORUFO ${ }^{1,2,11}$, \\ Béatrice BÉCHET ${ }^{5,12}$ and Jérôme CORTET ${ }^{8}$ \\ ${ }^{1}$ Université de Lorraine, Laboratoire Sols et Environnement, UMR 1120, Vandouvre-lès-Nancy 54500 (France) \\ ${ }^{2}$ INRA, Laboratoire Sols et Environnement, UMR 1120, Vandoeuvre-lès-Nancy 54500 (France) \\ ${ }^{3}$ UMR ECOSYS, INRA, AgroParisTech, Université Paris-Saclay, Thiverval-Grignon 78850 (France) \\ ${ }^{4}$ Plateforme d'Analyse Moléculaire Biodiversité-Environnement, IUT Génie Biologique, La Roche sur Yon 85035 (France) \\ ${ }^{5}$ Institut de Recherche sur les Sciences et Techniques de la Ville (IRSTV), CNRS 2488, Ecole Centrale de Nantes, 1 rue de la Noë, \\ Nantes 44321 (France) \\ ${ }^{6}$ Laboratoire Planétologie \& Géodynamique Nantes, Faculté des Sciences et des Techniques, 2 rue de la Houssinière, Nantes 44322 \\ (France) \\ ${ }^{7}$ Bureau de Recherches Géologiques et Minières (BRGM), Regional Geological Survey, Direction Régionale des Pays de la Loire, 1 \\ rue des Saumonières, Nantes 44000 (France) \\ ${ }^{8}$ UMR CEFE 5175, Université de Montpellier, EPHE, Université Paul-Valéry Montpellier, Montpellier 34199 (France) \\ ${ }^{9}$ Université Lille 1, EA 4515, Laboratoire Génie Civil \& Géo Environnement, Villeneuve D'Ascq 59655 (France) \\ ${ }^{10}$ Muséum National d'Histoire Naturelle, CNRS UMR 7179, 4 Avenue du Petit-Château, Brunoy 91800 (France) \\ ${ }^{11}$ Department of Biology, University of Naples Federico II, Via Cinthia, Naples 80126 (Italy) \\ ${ }^{12}$ French Institut of Science and Technology for Transport, Development and Networks, Water and Environment Laboratory, Route \\ de Bouaye, Bouguenais 44344 (France)
}

(Received November 13, 2017; revised April 10, 2018)

\begin{abstract}
Geogenic lead $(\mathrm{Pb})$ is considered to be less bioavailable than anthropogenic $\mathrm{Pb}$ and exerts less effect on the soil fauna. However, $\mathrm{Pb}$ contamination in vegetables has been reported in the case of geogenic anomalies, even at moderate concentrations (around $170 \mathrm{mg}$ $\mathrm{kg}^{-1}$ ). In this study, we investigated collembolan communities using both taxonomic- and trait-based approaches and observed fungal communities to assess the effects of a moderate geogenic $\mathrm{Pb}$ anomaly on collembolans and fungi in an urban vegetable garden soil. Results indicated that geogenic $\mathrm{Pb}$ indeed modified fungi communities and altered the functional structure of collembolan communities in garden soils. Although geogenic $\mathrm{Pb}$ presented low bioavailability, it affected soil fauna and vegetables similar to anthropogenic $\mathrm{Pb}$. Key Words: functional diversity, functional trait, soil fauna, soil food web, vegetable garden, urban soil
\end{abstract}

Citation: Joimel S, Capiaux H, Schwartz C, Hedde M, Lebeau T, Le Guern C, Nahmani J, Pernin C, Salmon S, Santorufo L, Béchet B, Cortet J. 2018. Effect of geogenic lead on fungal and collembolan communities in garden topsoil. Pedosphere. 28(2): 215-226.

\section{INTRODUCTION}

Urban allotment gardening is currently a growing worldwide phenomenon, especially in industrialized countries (Guitart et al., 2012). The chemical study of topsoil quality along an anthropization gradient has shown that these garden soils may contain metals, especially lead $(\mathrm{Pb})$ (Joimel et al., 2016). Lead is considered to be neurotoxic, even at low concentrations, beginning at $12 \mu \mathrm{g} \mathrm{L}^{-1}$ in the blood (European food safety norm). Thus, high $\mathrm{Pb}$ concentrations could induce health risks through the consumption of contaminated vegetables from allotment gardens. Lead contamina- tion results not only from human activities such as industry, car traffic, and refuse (El Khalil et al., 2013; Huot et al., 2013) but also from intensive gardening practices, such as the use of pesticides containing $\mathrm{Pb}$ (Belon et al., 2012). The presence of metals, such as $\mathrm{Pb}$, may also be of geogenic origin, resulting from metalliferous mineralization, inducing local naturally high concentrations in soils (Bourennane et al., 2010; Ander et al., 2013). However, urban vegetable garden soils usually also have a basic $\mathrm{pH}$ and a high rate of organic matter (Joimel et al., 2016), contributing to reduced $\mathrm{Pb}$ mobility. This assumption is especially true for geogenic $\mathrm{Pb}$, which is often considered to present lower

*Corresponding author. E-mail address: sophie.boulanger-joimel@inra.fr. 
bioavailability than anthropogenic $\mathrm{Pb}$.

Recent soil analyses, performed in 2011 and 2012 on allotment gardens in Nantes (France) (Bouquet et al., 2017), found elevated $\mathrm{Pb}$ concentrations averaging $170 \mathrm{mg} \mathrm{kg}^{-1}$, mainly of geogenic origin due to the alteration of a particular parent rock, rich in $\mathrm{Pb}$ bearing minerals (Jean-Soro et al., 2015). Despite $\mathrm{Pb}$ being primarily of geogenic origin and presenting moderate anomaly (2.5-times higher than background levels) (Bouquet et al., 2017), health risks have been demonstrated due to the consumption of contaminated vegetables from these allotment gardens, with the $\mathrm{Pb}$ concentrations in leeks, cabbage, and carrots exceeding the European regulatory standards by up to 25 times (Jean-Soro et al., 2015).

These results raise questions as to the effects of moderate anomalies in geogenic $\mathrm{Pb}$ on the soil biota. In fact, metals, such as $\mathrm{Pb}$, could also affect soil organisms, thereby inducing a decrease both in biodiversity and in soil biological activity (Giller et al., 1998), which are important factors in the provision of ecosystem services, such as food production (Scheu, 2003). Anthropogenic $\mathrm{Pb}$ contamination is often accused of impacting the soil fauna by inducing a decrease either in biodiversity or in the biological activity of some soil fauna groups, such as macrofauna (Nahmani et al., 2003), collembolans (Fountain and Hopkin, 2004a), and nematodes (Campos-Herrera et al., 2016; Gutiérrez et al., 2016).

However, to date, numerous studies have only concerned the effects of anthropogenic $\mathrm{Pb}$ contamination and/or elevated geogenic $\mathrm{Pb}$ concentrations (higher than $1000 \mathrm{mg} \mathrm{kg}^{-1}$ soil) (Russell and Alberti, 1998). In contrast, the effects of moderate geogenic $\mathrm{Pb}$ anomalies on soil fauna have as yet been scarcely studied.

The relationships between metal in the soil and fungi communities have been widely explored, but results of the studies trying to establish the effect of metal toxicity to soil microorganisms vary greatly (Giller et al., 1998). The increase in studies of the effects of metals on soil microorganisms is related to an increasing awareness of pollution issues (Båăth, 1989). A shift in a fungi species' composition induced by $\mathrm{Pb}$ contamination was found when $\mathrm{Pb}$ was present with $\mathrm{Cd}, \mathrm{Cu}$, and Zn as well as for Zn and Cd alone (Bååth, 1989). Again, major gaps in knowledge and theory exist as to how the microorganisms are exposed and respond to the metals in soils (Giller et al., 2009).

Among the soil fauna, collembolans are a key component of the food web and play a key role both in litter decomposition (Cortet et al., 2003) and nitrogen and carbon cycling (Filser, 2002) as well as in soil mi- croaggregation, and, therefore, in soil productivity as a whole. The primary role of collembolan is decomposition and the way the soil functions because they feed on detritus and/or fungi (O'Brien et al., 2005). In addition, soil fungi are partly influenced by collembolan grazing activity.

Relationships between metal in the soil and collembolan communities have mainly been explored using taxonomic approaches (including species richness, abundance, and community structure and composition). A functional trait-based approach would be complementary to these approaches because traits are properties of individuals that govern the responses to their environment (Pey et al., 2014b). For invertebrates, Pey et al. (2014b) defined a functional trait as being any morphological, physiological, phenological, or behavioral (MPPB) feature measurable at the individual level, without reference to any other level of organization. Over the last 20 years, functional trait investigations have contributed to highlighting the way in which environmental stressors impact plant selection (Lavorel and Garnier, 2002; Garnier et al., 2007) and more recently have included the effects on soil fauna too (Hedde et al., 2012; Santorufo et al., 2014a). For example, a study of the functional traits of ground beetles has shown their sensitivity to anthropogenic Zn contamination (Skalski et al., 2010).

Our study focuses on an allotment garden, which presents a local geogenic $\mathrm{Pb}$ anomaly with concentrations ranging from 97 to $314 \mathrm{mg} \mathrm{kg}^{-1}$ soil, which consequently induces $\mathrm{Pb}$ contamination in the vegetables consumed by gardeners (Jean-Soro et al., 2015). Within this framework, our objective was to evaluate the effect of this geogenic anomaly on collembolan and fungal communities. A single garden on an urban allotment with a pronounced $\mathrm{Pb}$ gradient was studied. We hypothesized that the total $\mathrm{Pb}$ concentration induced a direct chemical constraint on soil fauna that reduces the relative abundance of taxa exhibiting traits linked to $\mathrm{Pb}$ exposure (body length and localization in soil profile), avoidance (motion strategy), population recovery (reproduction type), and/or an indirect effect as a result of the change in the structure of the fungal community.

\section{MATERIALS AND METHODS}

Experimental site and soil characteristics at plot scale

An experiment was carried out on a $280-\mathrm{m}^{2}$ individual plot at the Eglantiers allotment garden located in Nantes (Loire-Atlantique, France). The climate is temperate oceanic with a mean temperature of $12{ }^{\circ} \mathrm{C}$ and 
a mean rainfall of $820 \mathrm{~mm}$ per year. At the beginning, the garden plot was divided into two sub-plots. Soil analysis was performed in autumn 2012. Twenty subsamples of cultivated topsoils $(0-20 \mathrm{~cm})$ were collected from each sub-plot and then mixed and homogenized to obtain two representative samples. Few differences were noticed in the main soil characteristics analyzed (Table I). The soil had a sandy loam texture and high nutrient contents. Its mineralogy mainly consisted of quartz (71\%); feldspars such as orthoclase (9\%) and plagioclase (8\%); phyllosilicates such as kaolinite $(6 \%)$; and traces of chlorite and illite or micas $(6 \%) . \mathrm{Cd}, \mathrm{Cu}$, and $\mathrm{Zn}$ were not considered as possible contaminants in this garden, conversely to the usually observed levels in urban vegetable gardens (Joimel et al., 2016).

In contrast, $\mathrm{Pb}$ was the major concern in this allotment garden, with a median of $171 \mathrm{mg} \mathrm{kg}^{-1}$, which was considered as highly anomalous compared to usual $\mathrm{Pb}$ concentrations both in French soils in general (Baize et $a l ., 2008$ ) and particularly in the district (Le Guern et al., 2013a, b). Lead in this garden is known to be geogenic, probably linked to mineralized veins rich in $\mathrm{Pb}$ bearing minerals in the parent material, which is constituted of mica schists (Jean-Soro et al., 2015). Lead speciation in the garden was also assessed through sequential extraction (Ure, 1996) following the Community Bureau of Reference (BCR) procedure (Bouquet et al., 2017). Four fractions were obtained: exchangeable $\mathrm{Pb}(1.2 \%), \mathrm{Pb}$ linked to the oxy/hydroxides of $\mathrm{Mn}$ and $\mathrm{Fe}(11.9 \%), \mathrm{Pb}$ linked to sulfides and organic matter $(4.6 \%)$, and the residual fraction $(82 \%)$.
TABLE I

Topsoil characteristics of an urban vegetable garden at the garden plot scale (values for two replicates, which were derived from 20 sub-replicates each) and sub-plot scale (32 sub-plots)

\begin{tabular}{lll}
\hline Characteristics & Scale & \\
\cline { 2 - 3 } & Plot & Sub-plot \\
\hline Sand (\%) & $57,58^{\mathrm{a})}$ & \\
Silt (\%) & $28,28^{\mathrm{a})}$ & \\
Clay (\%) & $13,14^{\mathrm{a})}$ & \\
pH & $7.4,7.4^{\mathrm{a})}$ & $\left.5.75-7.63^{\mathrm{b}}\right)$ \\
Organic matter $\left(\mathrm{g} \mathrm{kg}^{-1}\right)$ & $36,29^{\mathrm{a}}$ & \\
C:N & $14,13^{\mathrm{a})}$ & \\
CEC $\left(\mathrm{cmol}+\mathrm{kg}^{-1}\right)$ & $8.7,7.4^{\mathrm{a})}$ & \\
Total Pb $\left(\mathrm{mg} \mathrm{kg}^{-1}\right)$ & $133,208^{\mathrm{c})}$ & $97-314^{\mathrm{b}), \mathrm{c})}$ \\
Total Cu $\left(\mathrm{mg} \mathrm{kg}^{-1}\right)$ & $38,28^{\mathrm{c}}$ & \\
Total Zn $\left(\mathrm{mg} \mathrm{kg}^{-1}\right)$ & $\left.94,79^{\mathrm{c}}\right)$ & \\
Total Cd $\left(\mathrm{mg} \mathrm{kg}^{-1}\right)$ & $0.15,0.12^{\mathrm{c})}$ & \\
CaCl & & \\
\hline
\end{tabular}

a) Joimel (2015).

b) Jean-Soro et al. (2014).

c) Béchet et al. (2018).

\section{Soil characteristics at sub-plot scale}

In order to study the variations in $\mathrm{Pb}$ concentration at plot scale in greater detail, the garden was divided into 32 sub-plots of $6 \mathrm{~m}^{2}$ each separated by $50-\mathrm{cm}$ wide grass strips (Fig. 1). Total $\mathrm{Pb}, \mathrm{CaCl}_{2}$-extractable $\mathrm{Pb}$, and $\mathrm{pH}$ were analyzed in each of the 32 sub-plots. Total $\mathrm{Pb}$ concentrations ranged from 97 to $314 \mathrm{mg}$ $\mathrm{kg}^{-1}$, with a median of $197 \mathrm{mg} \mathrm{kg}{ }^{-1}$ (Jean-Soro et al., 2015). These values increased along the west-east gradient. Values of $\mathrm{CaCl}_{2}$-extractable $\mathrm{Pb}$ and $\mathrm{pH}$ also

\begin{tabular}{|c|c|c|c|}
\hline $\begin{array}{c}1^{*} \\
(220)\end{array}$ & $\begin{array}{l}2^{\star} \\
(211)\end{array}$ & $\begin{array}{c}3 \\
(248)\end{array}$ & $\begin{array}{l}4 \\
(314)\end{array}$ \\
\hline $\begin{array}{c}5 * \\
(208)\end{array}$ & $\begin{array}{c}6 \bullet \\
(204)\end{array}$ & $\begin{array}{l}7 \\
(197)\end{array}$ & $\begin{array}{l}8 \\
(236)\end{array}$ \\
\hline $\begin{array}{c}9 \\
(195)\end{array}$ & $\begin{array}{c}10 \\
(194)\end{array}$ & $\begin{array}{c}11^{\star} \\
(216)\end{array}$ & $\begin{array}{c}12^{\bullet} \\
(225)\end{array}$ \\
\hline $\begin{array}{l}13 * \\
(214)\end{array}$ & $\begin{array}{l}14^{\star} \\
(212)\end{array}$ & $\begin{array}{c}15 \\
(214)\end{array}$ & $\begin{array}{c}16^{\bullet} \\
(237)\end{array}$ \\
\hline $\begin{array}{c}17 \\
(194)\end{array}$ & $\begin{array}{c}18 \\
(153)\end{array}$ & $\begin{array}{l}19 * \\
(174)\end{array}$ & $\begin{array}{l}20 * 4 \\
(176)\end{array}$ \\
\hline $\begin{array}{c}21^{\star} \\
(166)\end{array}$ & $\begin{array}{l}22 \\
(164)\end{array}$ & $\begin{array}{c}23 \\
(160)\end{array}$ & $\begin{array}{c}24^{\star} \\
(171)\end{array}$ \\
\hline $\begin{array}{c}25 \\
(153)\end{array}$ & $\begin{array}{l}26 \star \bullet \\
(146)\end{array}$ & $\begin{array}{c}27 \\
(139)\end{array}$ & $\begin{array}{c}28 \\
(136)\end{array}$ \\
\hline $\begin{array}{c}29 * \\
(135)\end{array}$ & $\begin{array}{l}30 \\
(137)\end{array}$ & $\begin{array}{l}31 \\
(97)\end{array}$ & $\begin{array}{l}32 * \\
(116)\end{array}$ \\
\hline
\end{tabular}

Pb concentration gradient

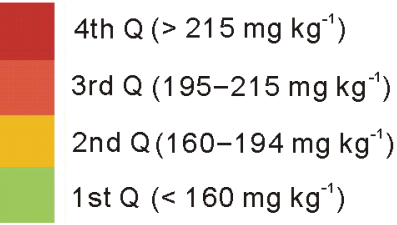

* Fungal sample

- Collembolan sample

Fig. 1 Distribution of total Pb concentrations (values in the parentheses) in the soil of urban vegetable garden (modified from Béchet et al., 2016). The garden plot was divided into 32 sub-plots of $6 \mathrm{~m}^{2}$ each separated by 50 -cm wide grass strips. Q $=$ quartile. 
varied according to this gradient.

Total $\mathrm{Pb}$ level of each sub-plot was analyzed $\mathrm{u}-$ sing a portable X-ray fluorescence tool (Niton 792). A selection of soil samples set for laboratory analysis by inductively coupled plasma mass spectrometry (ICP/MS) was obtained to calibrate the device. This method provides a semi-quantitative analysis of $\mathrm{Pb}$ concentrations, with a detection threshold of $4 \mathrm{mg}$ $\mathrm{kg}^{-1}$ (in $\mathrm{SiO}_{2}$ matrix). Blank tests and internal quality control samples were introduced into each series. The quality of the analyses was assessed by analyzing a reference soil, BCR-7002, using the same procedure. The quantification threshold was $0.1 \mu \mathrm{g} \mathrm{L}^{-1}$ for $\mathrm{Pb}$. Soil samples were dried for $5 \mathrm{~d}$ at $40{ }^{\circ} \mathrm{C}$ and prepared according to the NF ISO 11464 standard (AFNOR, 2006). Soil $\mathrm{pH}$ was measured according to the NF ISO 10390 standard (AFNOR, 1994), and mobile $\mathrm{Pb}$ was extracted with $0.01 \mathrm{~mol} \mathrm{~L}{ }^{-1} \mathrm{CaCl}_{2}$ for $2 \mathrm{~h}$ according to the NEN 5704 standard (1996).

\section{Soil fungi diversity sampling at sub-plot scale}

Fungi were sampled in April 2013. Among the 32 sub-plots, twelve replicates were randomly sampled along the concentration gradient (Fig. 1). Fifty grams of litter-free topsoil were collected from each of the subplots selected.

\section{Fungal DNA diversity analysis}

The fungal community structure was studied $\mathrm{u}$ sing polymerase chain reaction-temporal temperature gel electrophoresis (PCR-TTGE). DNA was extracted from soil samples $(0.5 \mathrm{~g})$ using the Nucleospin ${ }^{\circledR}$ soil kit (Macherey-Nagel GmbH \& Co, Düren, Germany). Before DNA analyses, soil samples were ground using a mixer mill (MM 400, Retsch, Haan, Germany) three times for a period of $30 \mathrm{~s}$ each at a frequency of 25 $\mathrm{Hz}$. The extracted DNA was quantified, and its quality was controlled using SPECTROstar Nano (BMG LABTECH LVi Plate, Offenburg, Germany). The 5.8S DNA region was amplified using ITS5-gc (forward) and ITS2 (reverse) primers (Joly et al., 2012). The final reaction volume totaling to $50 \mu \mathrm{L}$ comprised $1.2 \mathrm{ng} \mathrm{L}^{-1}$ of DNA template, $0.3 \mathrm{~mol} \mathrm{~L}{ }^{-1}$ of each primer, 200 mol L ${ }^{-1}$ of dNTPs, 0.012 unit (U) $\mathrm{L}^{-1}$ of Taq polymerase, $1 \times$ reaction buffer, $2.5 \mathrm{mmol} \mathrm{L}^{-1}$ of $\mathrm{MgCl}_{2}$,

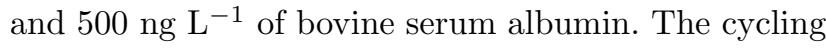
conditions were set as follows: 1 cycle at $95{ }^{\circ} \mathrm{C}$ for $15 \mathrm{~min}$, followed by 35 cycles of $95{ }^{\circ} \mathrm{C}$ for $30 \mathrm{~s}, 55$ ${ }^{\circ} \mathrm{C}$ for $45 \mathrm{~s}$, and $72{ }^{\circ} \mathrm{C}$ for $30 \mathrm{~s}$, and a final extension cycle at $72{ }^{\circ} \mathrm{C}$ for $7 \mathrm{~min}$ (CFX96 Touch $^{\mathrm{TM}}$, Thermal Cycler, Bio-Rad, USA). Analyses of TTGE were performed using a DCode ${ }^{\mathrm{TM}}$ system (Bio-Rad, Hercules,
USA). The polyacrylamide gel (9.5\%) (volume:volume) was composed of two parts: the upper, urea-free, "concentration" (stacking gel) of about $1 \mathrm{~cm}$ upward from the base of the wells, and the lower, "denaturation" part (resolving gel), at $8 \mathrm{~mol} \mathrm{~L}^{-1}$ urea. Fifteen microliters of PCR products were deposited in each well. Migration was performed in Tris-acetate-EDTA $1.25 \times$ buffer for $750 \mathrm{~min}$ at $50 \mathrm{~V}$, with a temperature gradient from 65 to $70{ }^{\circ} \mathrm{C}$, i.e., increasing the temperature at the rate of $0.4{ }^{\circ} \mathrm{C} \mathrm{h}^{-1}$. The gels were stained using GelRed $^{\text {TM }}$ (Biotium, Hayward, USA) and then imaged under ultraviolet (UV) light (Molecular Imager ${ }^{\circledR}$ Gel $\operatorname{Doc}^{\text {TM }}$ XR System and Image Lab ${ }^{\text {TM }}$ Software, BioRad, Hercules, USA). Microbial community structure analysis was performed from genetic fingerprints.

Fungal communities were described by composition, richness (mean number of taxa per sample), Shannon diversity index, and evenness index (diversity and distribution index per sample).

\section{Collembolan diversity sampling at sub-plot scale}

Collembolans were sampled in April 2013. Among the garden plots, 24 replicates were randomly sampled along the concentration gradient (Fig. 1). One sample of intact soil core ( $5 \mathrm{~cm}$ depth and $6 \mathrm{~cm}$ diameter) was collected per replicate.

\section{Collembolan diversity analysis}

Collembolans were extracted from soil samples $\mathrm{u}$ sing a high-gradient McFadyen extractor for one week (Petersen et al., 2003). Except for Mesaphorura, identified only at the genus level, collembolans were identified at the species level using various available dichotomous keys (Gisin, 1943; Zimdars and Dunger, 1995; Dunger, 1999; Potapow, 2001; Thibaud et al., 2004; Hopkin, 2007; Dunger and Schlitt, 2011; Jordana, 2012).

For the taxonomic approach, collembolan communities were described by density (abundance of each taxon per $\mathrm{m}^{2}$, richness (mean number of taxa per sample), Shannon diversity index, and evenness index (diversity and distribution index per sample).

For the functional approach, 8 functional traits and ecological performances were selected for their ability to reflect the effect of $\mathrm{Pb}$ exposure or avoidance on population recovery (Table II). Body shape, body length, visual organs, and pigmentation are related to the vertical distribution of collembolans in the soil (Ponge et al., 2006; Farská et al., 2014; Salmon et al., 2014). Reproduction type is related to their ability to colonize or survive after disturbances (Chernova et al., 2010). Motion strategy determines the ability of collembolan to 
TABLE II

Description and attributes of morphological, behavioral, and physiological traits considered for the trait-based approach of the collembolan community

\begin{tabular}{lll}
\hline Trait & Abbreviation & Attributes \\
\hline Body shape & BSH & Spherical, cylindrical \\
Body length & BLR & $<1,1-2,2-3,>3 \mathrm{~mm}$ \\
Motion strategy & MS & With, without furcula \\
Pigmentation & PIG & With, without coloration \\
Visual organ & VO & With, without ocelli \\
Reproduction & REP & Sexual, asexual \\
Habitat & HABI & Forest, agricultural, anthropogenic areas \\
Microhabitat & MHABI & Organic matter in decomposition, mineral soil, vegetation \\
\hline
\end{tabular}

jump using its furcula, e.g., to avoid predators. The ability to jump is defined by the presence of a short, reduced, or long furcula. Habitat and microhabitat indicate ecological preference and trophic strategy (Salmon et al., 2014).

Traits were obtained from the BETSI (biological and ecological functional traits of soil invertebrates) database on functional traits (CESAB/FRB) (Pey et al., 2014a). Data on functional traits were primarily adopted from identification keys in the literature (Gisin, 1943; Zimdars and Dunger, 1995; Dunger, 1999; Potapow, 2001; Thibaud et al., 2004; Hopkin, 2007; Dunger and Schlitt, 2011; Jordana, 2012). The trait matrix contained trait attribute scores, encoded using a fuzzy method (Chevene et al., 1994) and adapted to soil organisms (Hedde et al., 2013). Briefly, a species affinity percentage for each attribute of a trait was determined per source and then averaged through the sources to obtain the mean distribution of species affinity across the different attributes of a trait (i.e., the species trait profile).

In order to study the repartition of traits within the communities, we calculated the community weighted mean (CWM) for each trait. Community weighted mean is the sum of species trait profiles weighted by their relative abundance in the community (Lavorel et al., 2008). The multidimensional functional structure of collembolan communities was characterized by three distance-based functional diversity indices (Laliberté and Legendre, 2010), viz., functional richness (FRic), functional evenness (FEve), and functional divergence (FDiv), and Rao's quadratic entropy (RaoQ). These indices quantify different facets of the functional diversity for a community (Villéger et al., 2008); FRic represents the volume of the functional space occupied by a community, FEve corresponds to the regularity of the distribution of species abundance in a given volume, and FDiv is the divergence in the distribution of abundance in this volume (Laliberte and Legendre,
2010). In addition, we used the RaoQ index, which incorporates both the relative abundance of a species and a measure of the pairwise functional differences between the species (Botta-Dukát, 2005). The RaoQ index is a suitable approach to measure functional diversity, where several traits are considered (Pelosi et al., 2014). The maximum functional dissimilarity within the collembolan community was observed at a value of 1 .

\section{Statistics}

The effects of $\mathrm{Pb}$ concentrations on fungi and collembolan communities were investigated. Pearson's test was used to compare TTGE profiles between the fungi communities. The unweighted pair group method with an arithmetic mean (UPGMA) was used to construct a dendrogram from similarity coefficients (Ibekwe et al., 2010).

We analyzed the effect of $\mathrm{Pb}$ on the specific composition of collembolans by performing a principal coordinate analysis ( $\mathrm{PCoA})$ using the Bray-Curtis index to explore dissimilarities between the communities. The CWM values were compiled into a single matrix (26 taxa $\times 16 \mathrm{CWM}$ ). Then, we performed principal component analysis (PCA) to investigate the functional composition of collembolan communities. For binary attributes, only one attribute per taxa was used in PCA to avoid auto-correlation. Moreover, each variable in PCA was weighted by the number of attributes for each functional trait.

Pearson's test was again used to assess the correlations of the parameters describing fungal and collembolan communities with the $\mathrm{Pb}$ concentration gradient.

The significance level for all analyses was fixed at the rejection level of $P=0.05$. Analyses of TTGE profile were performed with FPQuest ${ }^{\mathrm{TM}}$ software (BioRad, Hercules, USA). Fungal community structure analysis was performed from genetic fingerprints. All statistical analyses for collembolan communities were 
performed using $\mathrm{R}$ software version 3.2.2 ( $\mathrm{R}$ Development Core Team, 2015) with vegan packages (Oksanen et al., 2014) for the taxonomic approach and the FD package (Laliberté and Legendre, 2010) for the functional approach. The ade4 package (Thioulouse et al., 1997) was used for multivariate analysis. All data mentioned in the results are mean values.

\section{RESULTS}

\section{Fungi}

Species richness varied between 5 and 10 species per plot, with 8 species on an average. Analysis of the fungal structure community revealed two clusters with $64.5 \%$ of similitude (Fig. 2). These two clusters were related to total $\mathrm{Pb}$ concentration. The first group included sub-plots with low $\mathrm{Pb}$ concentrations $(<197 \mathrm{mg}$ $\mathrm{kg}^{-1}$ ), except for Sub-plot 6 (204 $\left.\mathrm{mg} \mathrm{kg}^{-1}\right)$. The second group was composed of sub-plots with higher $\mathrm{Pb}$ concentrations $\left(>197 \mathrm{mg} \mathrm{kg}^{-1}\right.$ ), except for Sub-plot
20 (176 mg kg-1). The species richness, Shannon diversity index, and evenness index of fungal communities were not correlated to total and $\mathrm{CaCl}_{2}$-extractable $\mathrm{Pb}$ concentrations or to $\mathrm{pH}$ (Table III).

Taxonomic composition and structural collembolan communities

A total of 26 taxa were found in the garden topsoil, belonging to nine families, Brachystomellidae, Entomobryidae, Hypogastruridae, Isotomidae, Neelidae, Onychiuridae, Sminthuridae, Sminthurididae and Tullbergiidae. Three species were singletons and six species were doubletons. The most abundant species were Proisotoma minuta (Tullberg, 1871) (36\%), Parisotoma notabilis (Schaeffer, 1896) (29\%), and Folsomia similis (Bagnall, 1939) (18\%). Species with lower abundances were Protaphorura armata (Tullberg, 1869) and Entomobrya multifasciata (Tullberg, 1871). Mesaphorura sp. was also a frequent taxon.

Total collembolan density in the soil samples ran-

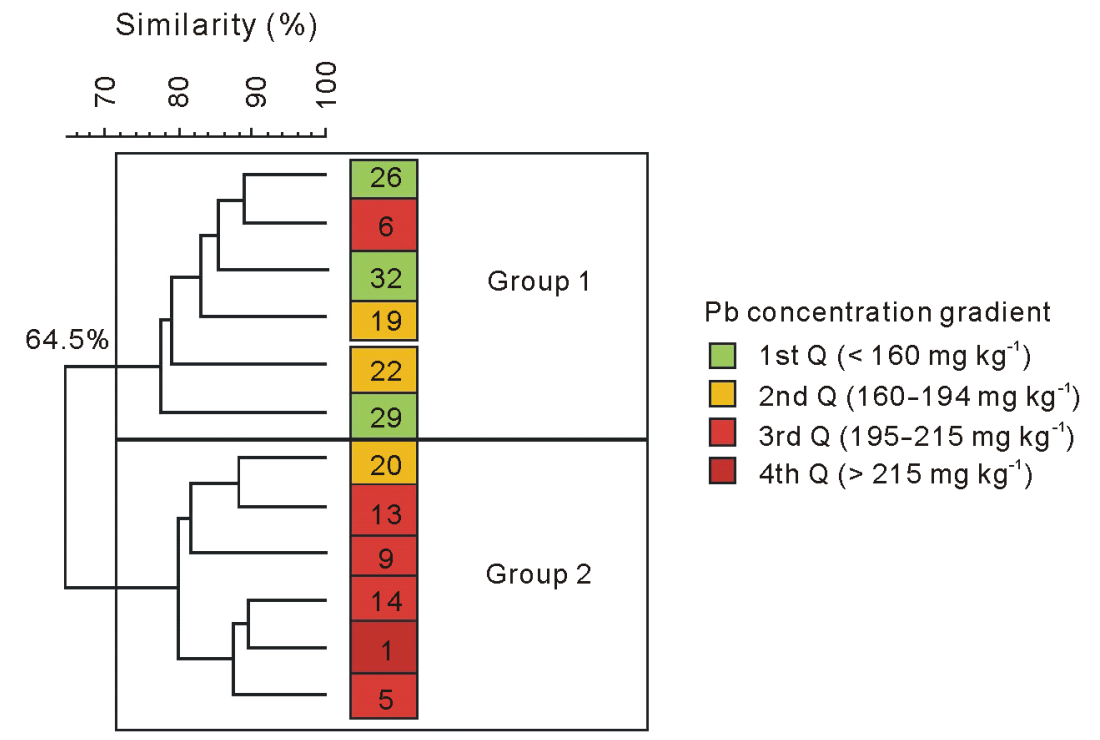

Fig. 2 Similarity between the fungi community of each sub-plot in garden soil along the gradient of total $\mathrm{Pb}$ concentration increasein soil. $\mathrm{Q}=$ quartile.

\section{TABLE III}

Species richness, Shannon diversity index, and evenness index of fungal community and Pearson's correlation coefficients $(r)$ with total $\mathrm{Pb}, \mathrm{CaCl}_{2}$-extractable $\mathrm{Pb}$, and $\mathrm{pH}$ in garden soil

\begin{tabular}{|c|c|c|c|c|c|c|}
\hline \multirow[t]{2}{*}{ Parameter } & \multirow[t]{2}{*}{ Min. $^{a)}$} & \multirow[t]{2}{*}{ Max. $^{\text {b) }}$} & \multirow[t]{2}{*}{ Mean } & \multicolumn{3}{|l|}{$r$} \\
\hline & & & & Total $\mathrm{Pb}$ & $\mathrm{CaCl}_{2}$-extractable $\mathrm{Pb}$ & $\mathrm{pH}$ \\
\hline Species richness & 5 & 10 & 7.8 & $-0.20 \mathrm{~ns}^{\mathrm{c})}$ & $-0.30 \mathrm{~ns}$ & $0.48 \mathrm{~ns}$ \\
\hline Shannon diversity index & 1.1 & 2.1 & 1.8 & $-0.40 \mathrm{~ns}$ & $-0.31 \mathrm{~ns}$ & $0.20 \mathrm{~ns}$ \\
\hline Evenness index & 0.4 & 0.6 & 0.6 & $-0.48 \mathrm{~ns}$ & $-0.22 \mathrm{~ns}$ & $-0.11 \mathrm{~ns}$ \\
\hline
\end{tabular}

a) Min. = minimum.

b) Max. = maximum.

c) Not significant. 
TABLE IV

Species richness, Shannon diversity index, evenness index, and density of collembolan community and Pearson's correlation coefficients $(r)$ with total $\mathrm{Pb}, \mathrm{CaCl}_{2}$-extractablePb, and $\mathrm{pH}$ in garden soil

\begin{tabular}{|c|c|c|c|c|c|c|}
\hline \multirow[t]{2}{*}{ Parameter } & \multirow[t]{2}{*}{ Min. ${ }^{a)}$} & \multirow[t]{2}{*}{ Max.b) } & \multirow[t]{2}{*}{ Mean } & \multicolumn{3}{|l|}{$r$} \\
\hline & & & & Total Pb & $\mathrm{CaCl}_{2}$-extractable $\mathrm{Pb}$ & $\mathrm{pH}$ \\
\hline Species richness & 6 & 13 & 10 & $-0.38 \mathrm{~ns}^{\mathrm{c})}$ & $0.06 \mathrm{~ns}$ & $-0.16 \mathrm{~ns}$ \\
\hline Shannon diversity index & 0.6 & 2.1 & 1.5 & $-0.35 \mathrm{~ns}$ & $-0.29 \mathrm{~ns}$ & $0.18 \mathrm{~ns}$ \\
\hline Evenness index & 0.3 & 0.8 & 0.6 & $-0.22 \mathrm{~ns}$ & $-0.32 \mathrm{~ns}$ & $0.25 \mathrm{~ns}$ \\
\hline Density $\left(\times 10^{3}\right.$ individuals $\left.\mathrm{m}^{-2}\right)$ & 19 & 505 & 123 & $0.03 \mathrm{~ns}$ & $0.21 \mathrm{~ns}$ & $-0.36 \mathrm{~ns}$ \\
\hline
\end{tabular}

a) Min. = minimum.

b) Max. = maximum

c) Not significant.

ged from about $19 \times 10^{3}$ to $505 \times 10^{3}$ individuals $\mathrm{m}^{-2}$ (Table IV). Other parameters also ranged widely. On an average, there were ten species, with the Shannon diversity index of 1.5 and evenness index of 0.6 per sub-plot. The first two axes of PCoA for collembolan species composition represented $51 \%$ of the total inertia (Fig. 3). The collembolan species composition varied depending on the sub-plot considered. No defined response to soil parameters, such as $\mathrm{Pb}$ concentration, was observed. The number of species, Shannon diversity index, evenness index, and density of collembolan communities were not correlated to total and $\mathrm{CaCl}_{2}$ extractable $\mathrm{Pb}$ concentrations and to $\mathrm{pH}$.

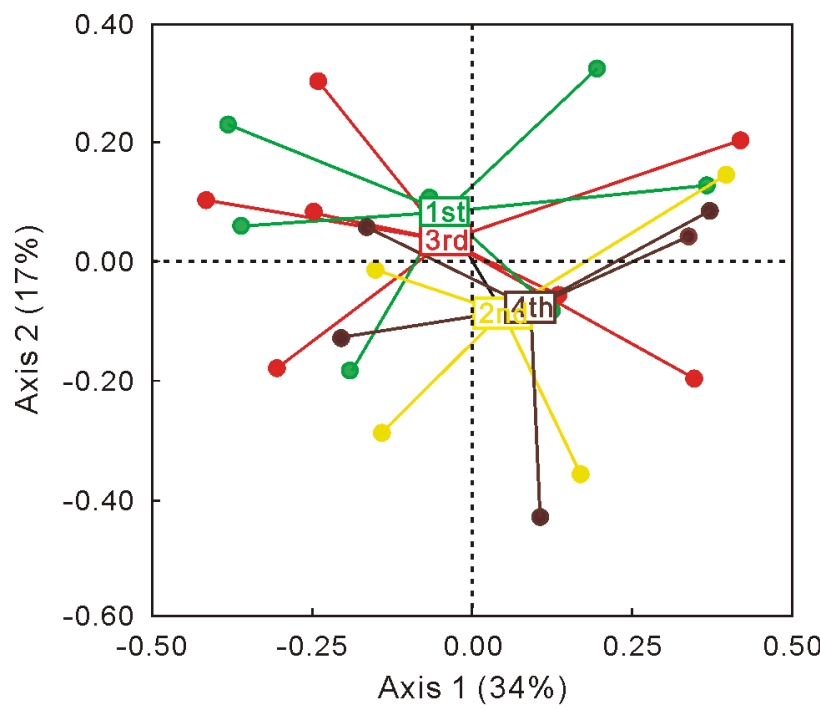

Fig. 3 Principal coordinate analysis ( $\mathrm{PCoA}$ ) of the specific composition of collembolans in garden soil along the gradient of total $\mathrm{Pb}$ concentration increase (4th quartile $(\mathrm{Q})>3$ rd $\mathrm{Q}>2$ nd $\mathrm{Q}>1$ st Q) in soil.

\section{Functional parameters of collembolan communities}

Based on CWM values, the main characteristics of collembolan communities were small bodied (1-2 mm) $(\mathrm{CWM}=76 \%)$, cylindrical $(\mathrm{CWM}=99 \%)$, with ocel- li $(\mathrm{CWM}=85 \%)$, with furcula $(\mathrm{CWM}=90 \%)$, pigmented $(\mathrm{CWM}=61 \%)$, and with sexual reproduction $(\mathrm{CWM}=74 \%)$. Concerning the ecological preferences for habitat, CWM values were $52 \%$ for forest, $28 \%$ for anthropogenic, and $19 \%$ for agricultural habitats. For microhabitat, CWM values were $7 \%$ for vegetation and $44 \%$ and $48 \%$ for decomposing organic matter and mineral soil, respectively.

The first two axes of PCA on CWM represented $68 \%$ of the total variability (Fig. 4). Axis 1 seemed to be related to species habitat and microhabitat preferences. Axis 2 represented an opposition between the organisms presenting pigmentation, ocelli, furcula, spherical body, and body length $>2 \mathrm{~mm}$ living in a vegetation microhabitat. The trait profile for Sub-plot 26 presented a higher differentiation than that of the other sub-plots.

However, two functional parameters of collembolan communities were significantly correlated to total $\mathrm{Pb}$ concentrations (Table V), viz., FRic and the RaoQ index, which significantly decreased as total soil Pb concentration increased. Concerning other indices and soil parameters, no significant relationship was observed, even if a tendency existed along the gradient towards a decrease in FEve.

\section{TABLE V}

Functional richness (FRic), functional divergence (FDiv), functional evenness (FEve), and Rao's quadratic entropy (RaoQ) of collembolan community and Pearson's correlation coefficients $(r)$ with total $\mathrm{Pb}, \mathrm{CaCl}_{2}$-extractable $\mathrm{Pb}$, and $\mathrm{pH}$ in garden soil

\begin{tabular}{lllll}
\hline Para- & Mean & $r$ & \\
\cline { 3 - 5 } meter & & Total $\mathrm{Pb}$ & $\mathrm{CaCl}_{2}$-extractable $\mathrm{Pb}$ & $\mathrm{pH}$ \\
\hline FRic & $8.06 \times 10^{-5}$ & $-0.41^{*}$ & $\left.-0.17 \mathrm{~ns}^{\mathrm{a}}\right)$ & $-0.19 \mathrm{~ns}$ \\
FDiv & 0.78 & $-0.07 \mathrm{~ns}$ & $0.24 \mathrm{~ns}$ & $-0.25 \mathrm{~ns}$ \\
FEve & 0.53 & $-0.31 \mathrm{~ns}$ & $-0.02 \mathrm{~ns}$ & $-0.05 \mathrm{~ns}$ \\
RaoQ & 0.03 & $-0.43^{*}$ & $-0.37 \mathrm{~ns}$ & $0.18 \mathrm{~ns}$ \\
\hline
\end{tabular}

*Significant at $P<0.05$.

a) Not significant. 

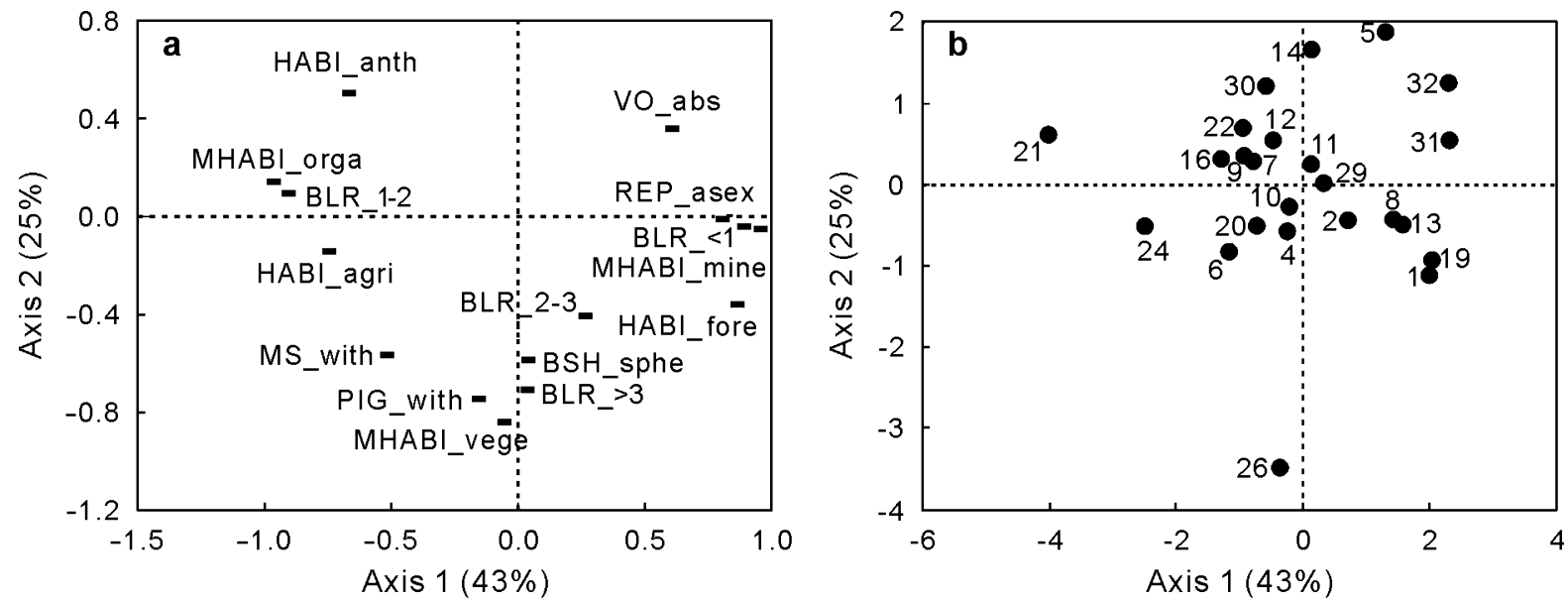

Fig. 4 Principal component analysis (PCA) of functional composition of collembolans based on values of community weighted mean (CMW) for 8 traits (a) in the 26 sub-plots of garden soil (b) (26 taxa, 24 CWM). Labels in Fig. 4b correspond to plot numbers along the decrease in total $\mathrm{Pb}$ concentration in soil. VO_abs = visual organ, without ocelli; BSH_sphe = body shape, spherical; BLR_<1, BLR_1-2, BLR_2-3, and BLR_>3 = body length, $<1,1-2,2-3$ or $>3$ mm, respectively; PIG_with = pigmentation, with coloration; REP_asex = parthogenesis reproduction; HABI_fore, HABI_agri, and HABI_anth = forest, agricultural, anthropogenic habitats, respectively; MHABI_orga, MHABI_mine, and MHABI_vege = microhabitat, organic matter in decomposition, mineral soil, and vegetation, respectively; MS_with = motion strategy, with furcula.

\section{DISCUSSION}

Numerous studies have dealt with the effect of anthropogenic $\mathrm{Pb}$ contamination on the microfauna and microorganisms, but only a few relate to geogenic $\mathrm{Pb}$. Yet, environmental and sanitary risks do indeed exist, even with this geogenic $\mathrm{Pb}$. In the present study, we investigated the effect of a moderate geogenic $\mathrm{Pb}$ anomaly in an urban vegetable garden on fungi, using a genetic fingerprinting method, as well as on its collembolan communities, using taxonomic and trait-based approaches.

Our results showed that geogenic $\mathrm{Pb}$ affected the composition of fungi communities. These results could be related to the potential toxicity of metals, as previously reported for anthropogenic metals on soil microorganisms (Giller et al., 1998), in particular on fungal diversity (Yang et al., 2015). The review of Bååth (1989) regarding the effects of metals on microbial populations noted, in numerous investigations, a reduction in both the abundance and biomass of fungi due to metals, often with a selection of tolerant species, but no clear effect on the number of taxa (or colony forming unit). Other effects on fungal biodiversity could be related to accumulation of metals in the fungal hyphae. However, in the present study, no correlation was demonstrated between the taxonomic parameters of fungi communities and total or extractable $\mathrm{Pb}$. These contrasting results could also be induced by the influence of other factors such as vegetation or cultivation practices. Several factors have been reported that influence the whole vegetable garden (Chenot et al., 2012) and, perhaps, soil biodiversity.

The collembolan community interacts with soil fungi within the soil food web. The metals in soil are largely transferred to and accumulated in collembolans, which are known to feed on fungi. To maximize their fitness, collembolans are able to adjust the proportion of food material they ingest (Scheu and Folger, 2004). In addition, collembolans can discriminate between fungal mycelium grown on a metal-contaminated medium and a medium that is not metal-contaminated (Pfeffer et al., 2010). Therefore, a Pb-related modification to fungal communities may, in turn, have affected collembolan communities.

In the vegetable garden, as $83 \%$ of the total collembolan abundance comprised only three species, the evenness index was low. This dominance of a few species in the collembolan community structure is often related to highly disturbed or contaminated sites (Russell and Alberti, 1998). Among the three abundant species, $P$. minuta and $P$. notabilis are widely distributed and frequently dominant in soils, including urban soils (Kuznetsova, 2003; Santorufo et al., 2014a). P. minuta predominance may be due both to the preference of this species for manure, which is widely used for managing garden soil fertility, and its high tolerance to stress (Santorufo et al., 2015). Although F. similis is rarely observed in Europe, it has been already noticed in garden soils. In this context, its relatively high abundance is not surprising, since the species is associated with composts (Gisin, 1943; Hopkin, 2007), which are widely present in gardens. The abundances of a dominant species and the evenness index were not, 
however, related to the soil $\mathrm{Pb}$ concentration. The hypothesis that the selection of tolerant taxa is associated to the conservation of more sensitive species at low abundance, involving a decrease in evenness (Fountain and Hopkin, 2004b), was not proven in the present study. However, the evenness index was very low across the whole garden, which could indicate that the index was not sensitive along a gradient but only to marked differences in metal concentration. Thus, in our stu$\mathrm{dy}$, the taxonomic diversity of collembolan species was not altered by higher geogenic $\mathrm{Pb}$ concentrations (total and extractable). This result is in accordance with previous studies on anthropogenic metals. For example, Winkler (2014) showed that, in a forest contaminated by various metals, including $\mathrm{Pb}$, collembolan species richness was almost the same in both metal-polluted and control forests. In contrast, Santorufo et al. (2012, 2014a) demonstrated a correlation between a decrease in species number and increased concentrations of $\mathrm{Cu}$, $\mathrm{Pb}$, and $\mathrm{Zn}$. However, our garden soil had a lower metal concentration than those of soils from other studies conducted in urban environments on anthropogenic $\mathrm{Pb}$ alone (i.e., higher than $200 \mathrm{mg} \mathrm{kg}^{-1}$ of anthropogenic $\mathrm{Pb}$ in Santorufo et al., 2012).

Moreover, even if collembolans feed mostly on fungi (Pollierer et al., 2012), they can also feed on organic matter such as feces (Ponge, 1991). The high organic matter content in garden soil (Joimel et al., 2016), often imported from non-contaminated sites, could provide a variety of food resources for collembolans, potentially allowing collembolan communities to avoid the negative effects of metal.

However, although there were differences between the community compositions of each sub-plot, no clear relationship between taxonomic composition and $\mathrm{Pb}$ or $\mathrm{pH}$ was observed. This shift in species distribution indicates the divergent responses of the community structure to their soil habitat.

Our results also showed an effect of geogenic $\mathrm{Pb}$ concentrations, but no effect of $\mathrm{pH}$, on the functional structure and composition of collembolan communities.

According to the functional trait-based approach, most collembolans in the garden shared a common trait profile, i.e., small-bodied $(<2 \mathrm{~mm})$, cylindrical, pigmented, and with ocelli, furcula, and sexual reproduction. Santorufo et al. (2014a) observed that the species most tolerant to urban environmental conditions, often in multi-contaminated soil, had a small body size, jumping motion strategy, sexual reproduction, and pigmentation. Furthermore, in our results, FRic and FDiv indices decreased along the gradient of total $\mathrm{Pb}$ con- centration increase, indicating a clear trend for species to share the same traits when $\mathrm{Pb}$ concentrations increase.

Higher pigmentation protects the organisms from UV radiation (Hopkin, 2007), whilst allowing sexual identification (Santorufo et al., 2015), thereby permitting organisms to survive on the surface. These organisms also have a high mobility owing to furcula and ocelli, thereby pointing to the ability of these organisms to avoid contamination. Natal da Luz et al. (2004) demonstrated the use of avoidance behavior by Folsomia candida in highly contaminated soils. Austruy et al. (2016) confirmed these exclusion/avoidance mechanisms for $\mathrm{Pb}$ in the case of highly polluted soils or soils with low metal bioavailability. Geogenic contamination often occurs at low bioavailability, which could explain the shifts in functional profiles along the contamination gradient.

Sexual reproduction could also represent an advantage over asexual reproduction in contaminated soil. Gillet and Ponge (2003) noted that Mesaphorura macrochaeta, a parthenogenic collembolan, can switch to sexual reproduction in soil polluted by $\mathrm{Zn}$.

In fact, the increased proportion of individuals with pigmentation, furcula, or ocelli is related to the selection of epigeic organisms (Salmon et al., 2014), which are less sensitive to environmental stress (Kærsgaard et al., 2004). These characteristics are more frequently observed in open habitats, such as vineyards and arable soils (Auclerc et al., 2009), and could also occur in vegetable gardens. Furthermore, this selection could be due to the advantages of epidaphic collembolans vs. eudaphic collembolans, which more frequently live in contact with more deeply contaminated soils.

The taxonomic approach provided no indication of the degree of $\mathrm{Pb}$ concentration, whereas changes in morphological traits and ecological preferences were indeed observed. Moreover, it seemed that the taxonomic indices of the fungal communities were less sensitive than fungal composition. This underlines the idea put forward by Ladygina et al. (2008) that it is not possible to detect responses to stress using general methods (e.g., determining the microbial biomass or numbers of collembolans) to determine food web components. In contrast, functional traits provide information on the community responses to $\mathrm{Pb}$ concentration effects, even if the concentration is moderate.

Finally, all these results highlight both a direct and perhaps an indirect effect of total geogenic $\mathrm{Pb}$ on soil biota. However, no relationship was reported with extractable $\mathrm{Pb}$, which could be explained by its low bioavailability. Similarly, the geogenic $\mathrm{Pb}$ transferred 
to vegetables (Jean-Soro et al., 2015) was not clearly related to extractible $\mathrm{Pb}$. However, it should be noted that the geogenic origin of $\mathrm{Pb}$ does not prevent its accumulation by vegetables or by soil biota. Indeed, the relationship between soil biota and extractable $\mathrm{Pb}$ or other metals is often complex. Some studies on collembolan failed to determine its relationship with extractable Pb (Santorufo et al., 2014b), whereas another study demonstrated the opposite (Luo et al., 2014). Beaumelle et al. (2014) mentioned this lack of genericity when studying the response of earthworms to moderately and multi-contaminated soils. Many other parameters could be involved and affect the relationship, in particular the divergent effects of different metals and complexity of soil textures (Beaumelle et al., 2014).

There is still no universally acceptable method for assessing soil bioavailable metal concentrations (Giller et al., 2009), and our results further highlight the need for reliable indicators to predict the effects of metals on soil biota, especially in case of moderate or geogenic contamination.

\section{CONCLUSIONS}

The geogenic origin of $\mathrm{Pb}$, even at moderate concentrations, does not prevent it from affecting the soil biota. These effects cause modifications to the fungal community and to the functional traits of collembolan communities. Indices based on functional structure, such as functional traits, are more sensitive than those based on taxonomic structure, when used to study the effect of $\mathrm{Pb}$, even of geogenic origin. These indicators could also be used to better understand the relationship between organisms in soil food web.

\section{ACKNOWLEDGEMENTS}

We would like to thank the gardeners and all the partners involved in the JASSUR program for their substantial help, particularly Dr. Armelle Braud and Alain Rakoto. This work was supported by the ANR (French National Agency of Research, JASSUR research project; ANR-12-VBDU-0011). The authors wish to thank their colleagues from the BETSI project (FRB-CESAB) for their work on functional traits.

\section{REFERENCES}

Ander E L, Johnson C C, Cave M R, Palumbo-Roe B, Nathanail C P, Lark R M. 2013. Methodology for the determination of normal background concentrations of contaminants in English soil. Sci Total Environ. 454-455: 604-618.

Association Française de Normalisation (AFNOR). 1994. NF
ISO 11464, Soil Quality - pH Determination (In French). AFNOR, Paris

Association Française de Normalisation (AFNOR). 2006. NF ISO 11464, Soil Quality - Pre-treatment of Samples for Physico-Chemical Analysis (in French). AFNOR, Paris.

Auclerc A, Ponge J F, Barot S, Dubs F. 2009. Experimental assessment of habitat preference and dispersal ability of soil springtails. Soil Biol Biochem. 41: 1596-1604.

Austruy A, Laplanche C, Mombo S, Dumat C, Deola F, Gers C. 2016. Ecological changes in historically polluted soils: Metal(loid) bioaccumulation in microarthropods and their impact on community structure. Geoderma. 271: 181-190.

Bååth E. 1989. Effects of heavy metals in soil on microbial processes and populations (a review). Water Air Soil Pollut. 47: 335-379.

Baize D, Deslais W, Saby N P A. 2008. Eight Trace Elements (Cd, Cr, Cu, Hg, Ni, Pb, Se, Zn) in Agricultural Soils in France. Results of Data Collection at the National Level (in French). Final Report. Agence De l'Environnement et de la Maitrise de Energie, Angers.

Beaumelle L, Lamy I, Cheviron N, Hedde M. 2014. Is there a relationship between earthworm energy reserves and metal availability after exposure to field-contaminated soils? Environ Pollut. 191: 182-189.

Béchet B, Joimel S, Jean-Soro L, Hursthouse A, Agboola A, Leitão T E, Costa H, Do Rosário Cameira M, Le Guern C, Schwartz C, Lebeau T. 2018. Spatial variability of trace elements in allotment gardens of four European cities: Assessments at city, garden, and plot scale. J Soil Sediment. 18: 391-406.

Belon E, Boisson M, Deportes I Z, Eglin T K, Feix I, Bispo A O, Galsomies L, Leblond S, Guellier C R. 2012. An inventory of trace elements inputs to French agricultural soils. Sci Total Environ. 439: 87-95.

Botta-Dukát Z. 2005. Rao's quadratic entropy as a measure of functional diversity based on multiple traits. J Veg Sci. 16: 533-540.

Bouquet D, Braud A, Lebeau T. 2017. Brassica juncea tested on urban soils moderately contaminated by lead: Origin of contamination and effect of chelates. Int $J$ Phytoremediation. 19: 425-430.

Bourennane H, Douay F, Sterckeman T, Villanneau E, Ciesielski H, King D, Baize D. 2010. Mapping of anthropogenic trace elements inputs in agricultural topsoil from Northern France using enrichment factors. Geoderma. 157: 165-174.

Campos-Herrera R, Rodríguez Martín J A, Escuer M, García-González M T, Duncan L W, Gutiérrez C. 2016. Entomopathogenic nematode food webs in an ancient, mining pollution gradient in Spain. Sci Total Environ. 572: 312-323.

Chenot E D, Douay F, Dumat C, Pernin C, Pourrut B, Schwartz C. 2012. Jardins Potagers: Terres Inconnues (in French)? EDP Sciences, Les Ulis.

Chernova N M, Potapov M B, Savenkova Y Y, Bokova A I. 2010. Ecological significance of parthenogenesis in Collembola. Entomol Rev. 90: 23-38

Chevene F, Doléadec S, Chessel D. 1994. A fuzzy coding approach for the analysis of long-term ecological data. Freshw Biol. 31: 295-309.

Cortet J, Joffre R, Elmholt S, Krogh P H. 2003. Increasing species and trophic diversity of mesofauna affects fungal biomass, mesofauna community structure and organic matter decomposition processes. Biol Fert Soils. 37: 302-312.

Dunger W, Schlitt B. 2011. Synopses on Palaearctic Collembola. Vol. 6, Part 1. Onychiuroidea: Tullbergiidae. State Museum of the Natural History Museum of Görlitz, Görlitz. 
Dunger W. 1999. Synopses on Palaearctic Collembola. Vol. 2. Symphypleona. Staatliches Museum für Naturkunde Görlitz, Görlitz.

El Khalil H, Schwartz C, El Hamiani O, Kubiniok J, Morel J L, Boularbah A. 2013. Distribution of major elements and trace metals as indicators of technosolisation of urban and suburban soils. J Soil Sediment. 13: 519-530.

Farská J, Prejzková K, Rusek J. 2014. Management intensity affects traits of soil microarthropod community in montane spruce forest. Appl Soil Ecol. 75: 71-79.

Filser J. 2002. The role of Collembola in carbon and nitrogen cycling in soil. Pedobiologia. 46: 234-245.

Fountain M T, Hopkin S P. 2004a. A comparative study of the effects of metal contamination on Collembola in the field and in the laboratory. Ecotoxicology. 13: 573-587.

Fountain M T, Hopkin S P. 2004b. Biodiversity of Collembola in urban soils and the use of Folsomia candida to assess soil 'quality'. Ecotoxicology. 13: 555-572.

Garnier E, Lavorel S, Ansquer P, Castro H, Cruz P, Dolezal J, Eriksson O, Fortunel C, Freitas H, Golodets C, Grigulis K, Jouany C, Kazakou E, Kigel J, Kleyer M, Lehsten V, Lepš J, Meier T, Pakeman R, Papadimitriou M, Papanastasis V P, Quested H, Quétier F, Robson M, Roumet C, Rusch G, Skarpe C, Sternberg M, Theau J P, Thébault A, Vile D, Zarovali M P. 2007. Assessing the effects of land-use change on plant traits, communities and ecosystem functioning in grasslands: A standardized methodology and lessons from an application to 11 European sites. Ann Bot. 99: 967-985.

Giller K E, Witter E, Mcgrath S P. 1998. Toxicity of heavy metals to microorganisms and microbial processes in agricultural soils: A review. Soil Biol Biochem. 30: 1389-1414.

Giller K E, Witter E, McGrath S P. 2009. Heavy metals and soil microbes. Soil Biol Biochem. 41: 2031-2037.

Gillet S, Ponge J F. 2003. Changes in species assemblages and diets of Collembola along a gradient of metal pollution. App Soil Ecol. 22: 127-138.

Gisin H. 1943. Ökologie und lebensgemeinschaften der collembolen im schweizerischen exkursionsgebiet basels. Rev Suisse Zool (in German). 50: 131-224.

Guitart D, Pickering C, Byrne J. 2012. Past results and future directions in urban community gardens research. Urban For Urban Gree. 11: 364-373.

Gutiérrez C, Fernández C, Escuer M, Campos-Herrera R, Beltrán Rodríguez M E, Carbonell G, Rodríguez Martín J A. 2016. Effect of soil properties, heavy metals and emerging contaminants in the soil nematodes diversity. Environ Pollut. 213: 184-194.

Hedde M, Van Oort F, Boudon E, Abonnel F, Lamy I. 2013. Responses of soil macroinvertebrate communities to Miscanthus cropping in different trace metal contaminated soils. Biomass Bioenerg. 55: 122-129.

Hedde M, Van Oort F, Lamy I. 2012. Functional traits of soil invertebrates as indicators for exposure to soil disturbance. Environ Pollut. 164: 59-65.

Hopkin S P. 2007. A Key to the Collembola (Springtails) of Britain and Ireland. Field Studies Council, Shrewsbury.

Huot H, Simonnot M O, Marion P, Yvon J, De Donato P, Morel J L. 2013. Characteristics and potential pedogenetic processes of a Technosol developing on iron industry deposits. $J$ Soil Sediment. 13: 555-568.

Ibekwe A M, Papiernik S K, Grieve C M, Yang C H. 2010. Influence of fumigants on soil microbial diversity and survival of E. coli O157:H7. J Environ Sci Health B. 45: 416-426.

Jean-Soro L, Le Guern C, Bechet B, Lebeau T, Ringeard M F. 2015. Origin of trace elements in an urban garden in Nantes,
France. J Soil Sediment. 15: 1802-1812.

Joimel S, Cortet J, Jolivet C C, Saby N P A, Chenot E D, Branchu P, Consalès J N, Lefort C, Morel J L, Schwartz C. 2016. Physico-chemical characteristics of topsoil for contrasted forest, agricultural, urban and industrial land uses in France. Sci Total Environ. 545-546: 40-47.

Joly P, Besse-Hoggan P, Bonnemoy F, Batisson I, Bohatier J, Mallet C. 2012. Impact of maize formulated herbidcides, Mesotrione and S-Metolachlor, applied alone and in mixture, on soil microbial communities. ISRN Ecol. 2012: ID 329898.

Jordana R. 2012. Synopses on Palaearctic Collembola, Vol. 7, Part 1: Capbryinae \& Entomobryini. Senckenberg Museum of Natural History, Goerlitz.

Kærsgaard C W, Holmstrup M, Malte H, Bayley M. 2004. The importance of cuticular permeability, osmolyte production and body size for the desiccation resistance of nine species of Collembola. J Insect Phys. 50: 5-15.

Kuznetsova N A. 2003. New approaches to the assessment of structural organization of communities in springtails (Hexapoda: Collembola). Russ J Ecol. 34: 248-254.

Ladygina N, Caruso T, Hedlund K. 2008. Dietary switching of collembola in grassland soil food webs. Soil Biol Biochem. 40: $2898-2903$

Laliberté E, Legendre P. 2010. A distance-based framework for measuring functional diversity from multiple traits. Ecology. 91: 299-305.

Lavorel S, Garnier E. 2002. Predicting changes in community composition and ecosystem functioning from plant traits: revisiting the Holy Grail. Funct Ecol. 16: 545-556.

Lavorel S, Grigulis K, McIntyre S, Williams N S G, Garden D, Dorrough J, Berman S, Quétier F, Thébault A, Bonis A. 2008. Assessing functional diversity in the field-methodology matters! Funct Ecol. 22: 134-147.

Le Guern C, Baudouin V, Conil P, Courtais B, Houel M, Coffinet A, Latourte C, Gourmelen F. 2013a. METOTRASS: Méthodologie Optimisée Pour L'évaluation des Teneurs en Éléments Trace (As, Pb, Cu, Zn) Dans les Sols En Domaine de Socle: Test sur le Département de la Loire-Atlantique (in French). Final Report. Agence De l'Environnement et de la Maitrise de Energie, Angers.

Le Guern C, Baudouin V, Courtais B, Conil P, Gloaguen C, Roussel H. 2013b. Optimising Ways of Mapping the Natural Enrichment of Trace Elements in Soils Developed on Basement - Results on the French Department of LoireAtlantique (1/50 000). AquaConsoil 2013, Barcelona.

Luo W, Verweij R A, Van Gestel C A M. 2014. Assessment of the bioavailability and toxicity of lead polluted soils using a combination of chemical approaches and bioassays with the collembolan Folsomia candida. J Hazard Mater. 280: 524530.

Nahmani J, Lavelle P, Lapied E, Van Oort F. 2003. Effects of heavy metal soil pollution on earthworm communities in the north of France. Pedobiologia. 47: 663-669.

Natal da Luz T, Ribeiro R, Sousa J P. 2004. Avoidance tests with collembola and earthworms as early screening tools for sitespecific assessment of polluted soils. Environ Toxicol Chem. 23: 2188-2193.

O'Brien H E, Parrent J L, Jackson J A, Moncalvo J M, Vilgalys R. 2005. Fungal community analysis by large-scale sequencing of environmental samples. Appl Environ Microbiol. 71: 5544-5550.

Oksanen J, Blanchet G, Roeland K, Legendre P, Minchin P R, O'Hara R B, Simpson G L, Solymos P, Stevens M H H, Wagner H, 2014. Vegan: Community Ecology Package. R package 280 . 
Pelosi C, Pey B, Hedde M, Caro G, Capowiez Y, Guernion M, Peigné J, Piron D, Bertrand M, Cluzeau D. 2014. Reducing tillage in cultivated fields increases earthworm functional diversity. Appl Soil Ecol. 83: 79-87.

Petersen S O, Henriksen K, Mortensen G K, Krogh P H, Brandt K K, Sørensen J, Madsen T, Petersen J, Grøn C. 2003. Recycling of sewage sludge and household compost to arable land: Fate and effects of organic contaminants, and impact on soil fertility. Soil Till Res. 72: 139-152.

Pey B, Laporte M A, Nahmani J, Auclerc A, Capowiez Y, Caro G, Cluzeau D, Cortet J, Decaëns T, Dubs F, Joimel S, Guernion M, Briard C, Grumiaux F, Laporte B, Pasquet A, Pelosi C, Pernin C, Ponge J F, Salmon S, Santorufo L, Hedde M. 2014a. A thesaurus for soil invertebrate trait-based approaches. PLoS ONE. 9: e108985.

Pey B, Nahmani J, Auclerc A, Capowiez Y, Cluzeau D, Cortet J, Decaëns T, Deharveng L, Dubs F, Joimel S, Briard C, Grumiaux F, Laporte M A, Pasquet A, Pelosi C, Pernin C, Ponge J F, Salmon S, Santorufo L, Hedde M. 2014b. Current use of and future needs for soil invertebrate functional traits in community ecology. Basic Appl Ecol. 15: 194-206.

Pfeffer S P, Khalili H, Filser J, 2010. Food choice and reproductive success of Folsomia candida feeding on coppercontaminated mycelium of the soil fungus Alternaria alternata. Pedobiologia. 54: 19-23.

Pollierer M M, Dyckmans J, Scheu S, Haubert D. 2012. Carbon flux through fungi and bacteria into the forest soil animal food web as indicated by compound-specific ${ }^{13} \mathrm{C}$ fatty acid analysis. Funct Ecol. 26: 978-990.

Ponge J F, Dubs F, Gillet S, Sousa J P, Lavelle P. 2006. Decreased biodiversity in soil springtail communities: The importance of dispersal and landuse history in heterogeneous landscapes. Soil Biol Biochem. 38: 1158-1161.

Ponge J F. 1991. Food resources and diets of soil animals in a small area of Scots pine litter. Geoderma. 49: 33-62.

Potapow M. 2001. Synopses on Palaearctic Collembola. Vol. 3. Isotomidae. State Museum of the Natural History Museum of Görlitz, Görlitz.

Russell D J, Alberti G. 1998. Effects of long-term, geogenic heavy metal contamination on soil organic matter and microarthropod communities, in particular Collembola. Appl Soil Ecol. 9: $483-488$.

Salmon S, Ponge J F, Gachet S, Deharveng L, Lefebvre N, Delabrosse F. 2014. Linking species, traits and habitat characteristics of Collembola at European scale. Soil Biol Biochem. 75: $73-85$
Santorufo L, Cortet J, Arena C, Goudon R, Rakoto A, Morel J L, Maisto G. 2014a. An assessment of the influence of the urban environment on collembolan communities in soils using taxonomy- and trait-based approaches. Appl Soil Ecol. 78: $48-56$.

Santorufo L, Cortet J, Nahmani J, Pernin C, Salmon S, Pernot A, Morel J L, Maisto G. 2015. Responses of functional and taxonomic collembolan community structure to site management in Mediterranean urban and surrounding areas. Eur $J$ Soil Biol. 70: 46-57.

Santorufo L, Van Gestel C A M, Maisto G. 2014b. Sampling season affects conclusions on soil arthropod community structure responses to metal pollution in Mediterranean urban soils. Geoderma. 226-227: 47-53.

Santorufo L, Van Gestel C A M, Rocco A, Maisto G. 2012. Soil invertebrates as bioindicators of urban soil quality. Environ Pollut. 161: 57-63.

Scheu S. 2003. Effects of earthworms on plant growth: Patterns and perspectives. Pedobiologia. 47: 846-856.

Scheu S, Folger M. 2004. Single and mixed diets in Collembola: effects on reproduction and stable isotope fractionation. Funct Ecol. 18: 94-102.

Skalski T, Stone D, Kramarz P, Laskowski R. 2010. Ground beetle community responses to heavy metal contamination. Baltic J Coleopterol. 10: 1-12.

Thibaud J M, Schulz H J, Da Gama Assalino M M. 2004. Synopses on Palaearctic Collembola. Vol. 4. Hypogastruridae. State Museum of the Natural History Museum of Görlitz, Görlitz.

Thioulouse J, Chessel D, Dolédec S, Olivier J M. 1997. ADE-4: A multivariate analysis and graphical display software. Stat Comput. 7: 75-83.

Ure A M. 1996. Single extraction schemes for soil analysis and related applications. Sci Total Environ. 178: 3-10.

Villéger S, Mason N W H, Mouillot D. 2008. New multidimensional functional diversity indices for a multifaceted framework in functional ecology. Ecology. 89: 2290-2301.

Winkler D. 2014. Collembolan response to red mud pollution in Western Hungary. Appl Soil Ecol. 83: 219-229.

Yang Y R, Song Y Y, Scheller H V, Ghosh A, Ban Y H, Chen H, Tang M. 2015. Community structure of arbuscular mycorrhizal fungi associated with Robinia pseudoacacia in uncontaminated and heavy metal contaminated soils. Soil Biol Biochem. 86: 146-158.

Zimdars B, Dunger W. 1995. Synopses on Palaearctic Collembola. Vol. 1. Tullbergiinae. State Museum of the Natural History Museum of Görlitz, Görlitz. 